\title{
BUSINESS OPPORTUNITIES IN INDUSTRIAL REVOLUTION 4.0 THROUGH 9 (NINE) E-COMMERCE MARKETING STRATEGIES
}

\author{
${ }^{1}$ Wahyu Sardjono \\ Information Systems Management, Binus Graduate Program, Bina Nusantara University \\ J1. Kebon Jeruk Raya No. 27, Kebon Jeruk, Jakarta Barat 11530 - Indonesia \\ awahyu.s@binus.ac.id
}

\author{
${ }^{2}$ Winda Dian Nuriana \\ Master of Management, Faculty of Economic and Business, University of Gajahmada, Yogyakarta, Indonesia
}

\begin{abstract}
Technological developments in industry 4.0 which lead to digital technology create new ideas for companies to take strategic steps in business processes. One of them is utilizing electronic commerce. This study uses a qualitative analysis approach which uses secondary data. The methodology used is conceptual review by gathering data and information that are interrelated. The information collected is market opportunity, consumer behavior and electronic commerce technology as an innovation in marketing. This research is expected to create potential market opportunities. The marketing strategy used is the strategy of utilizing technology, market opportunities, marketing strategies, designing consumer knowledge, creating consumer interfaces, increasing customer information creating marketing programs, and evaluating marketing programs using technology and information and program evaluation.
\end{abstract}

Keywords: industrial community 4.0, ecommerce, consumer behavior, marketing strategies, technology.

\section{INTRODUCTION}

The industrial revolution 4.0 is a change by a group of people or organizations and individuals in a unit of time which is the impact of technological innovation which creates opportunities to develop, exchange, and distribute or distribute value to society with digital-based political dynamics [1]. The industrial revolution cannot be avoided from various aspects of the industry. One of the effects of the industrial revolution is the development of digital technology. This development combines conventional media with technology and digital media. The development of digital technology in the industrial revolution encouraged all industries to keep abreast of developments. One of the technological developments is the media in which the media developed into online media. Online media is almost used in all countries especially in developed countries. Most people in the world have enjoyed the development of online media technology. Online media, for example, are social media and electronic commerce (e-commerce). Social media or social networking has many impacts at this time. The use of social media by utilizing the internet network creates ease in connecting between individuals and time and cost efficiency in delivering information. One example of social media is Facebook, Instagram, and Twitter. Besides social media, another social media is electronic commerce or e-commerce.

The development of ecommerce in the world and in Indonesia today has recorded significant progress. The existence of ecommerce provides the opportunity and convenience to trade transactions directly between suppliers and prospective buyers. With the ecommerce supply of goods between sellers and buyers can have a shorter supply chain compared to the conventional buying and selling process. Based on iprice internet data, it is shown that ecommerce which is a 2019 Indonesian market player occupying the first rank is Shopee with an average monthly visitor of $72,973,300$ visitors.

Big players in ecommerce have positions that are easily replaceable and not absolute. Indonesian ecommerce that dominates competition in its industry is Tokopedia. Diversified content such as bonus coin games, live streaming, ticketing partnerships, and collaboration with local brands are the most reliable ecommerce formulas for increasing application user activity. However, Indonesia currently still lacks local ecommerce applications that can bring users who have experience at the top class. At present Tokopedia, which consistently accommodates the convenience of the Indonesian people for shopping, shopping applications with heterogeneous product catalogs became popular in 2019 , where having integrated products from various categories. While shopping applications that rely on homogeneous product catalogs are less successful in gathering a significant 
number of active monthly users by the end of 2019. Ecommerce developed into one marketing strategy which is used in business operations one of which is as a means for launching new products, developing customer loyalty through membership or membership and dissemination of product information. with the advantages of ecommerce in marketing strategies these conditions can be used as opportunities for business people to market their products to consumers through media that are more efficient and effective in terms of financing and time and energy. However, the use of ikamart at this time can be further optimized especially for other purposes such as ad productivity and promotion strategies. Based on the previous information and presentation, the formulation of the problem in discussing this topic is to study strategies that can be used to maximize the use of ecommerce in the industrial revolution 4.0

\section{Literature Review}

The movement of change was initiated because of technological developments and processing changes that underpinned the emergence of the industrial revolution 4.0, which was more than opening wide interactions but also disrupted important aspects of human life globally [2]. The industrial revolution showed a significant change in humans when going through a production process where the first time in 1750 was the industrial revolution 1.0. During that era, there were significant major changes in various fields of industry such as mining, transportation industry activities, and technology that had an impact on the condition of the community. In the 1.0 industrial revolution which is history that begins with the appearance of the engine as a substitute for conventional power that ever existed. Since the existence of the engine creates progress in the industry both for economic, cultural and social in the world community. The next stage of the industrial revolution is the 2.0 industrial revolution where there is a rapid development compared to the industrial revolution 1.0. the development of the industrial revolution 2.0 marked by the existence of macro inventions with innovations in various fields through the use of machine tools and developing methods used for the process. In the 2.0 industrial revolution the innovations that emerged were inventions such as telephone sets, car inventions and aircraft which were the beginning of change and development of the world. The 3.0 industrial revolution can be distinguished by the existence of digital technology and the beginning of the first internet where efficiency occurred between time and distance. The existence of the 3.0 industrial revolution began to change the process in the community to exchange information through the communication process. In addition, the development of the engine can create maximum fulfillment to meet the needs. The most recent industrial revolution is the industrial revolution 4.0 which is the latest development from the first to the last industrial revolution with the addition of technology that creates fast development by maximizing output with minimal input use. The industrial revolution 4.0 is expected to increase industrial competitiveness by utilizing technology and digital in various fields where it is expected to be able to offer more benefits by being able to respond to the challenges that are happening now where challenges are increasingly complex globally.

Electronic Commerce (ecommerce) is a concept that was created and introduced which is commonly described as the process of selling and purchasing goods or services on the virtual space of the World Wide Web Internet [3]. Ecommerce creates a huge impact both on the business side, consumers, and society in general. Economic growth and development will be created due to the impact of today's widespread e-commerce. Economic growth is faster than conventional trade which requires face to face meetings or direct meetings between sellers and prospective buyers [4]. Ecommerce that is developing in Indonesia currently has many benefits and potentials that can be developed, one of which is developing trading transactions between suppliers and prospective buyers online, helping companies to disseminate information related to products, helping companies to develop business through online media, as a means company to do promotions and can have a relationship with consumers. But now there are so many uses that deviate from the advantages of ecommerce as there is a false news [5].

Based on 2019 data, the most visited ecommerce sites in Indonesia are Tokopedia ranked first, Shopee ranked second, Bukalapak and then followed by Lazada, Blibli, JD id, Sociolla, Bhinneka, Orami, and lastly occupied by Zalora. When compared between semester 1 and semester 2 data in 2019 where the first rank is Tokopedia at the end of the year Shopee can outperform so as to make Tokopedia be ranked second. The level of sales in ecommerce occurred during the Ramadan Sale period and national online shopping day. The increase in sales was dominated by more than $60 \%$ by millennial consumers, while based on online learning platforms carried out via mobile compared to purchases through desktops with a figure of more than $90 \%$. Based on the data it can be concluded that the promotion conducted by the seller through e-commerce is very volatile but from the other side there are significant differences in the promo period and can be an opportunity for the company to promote product sales to consumers. 


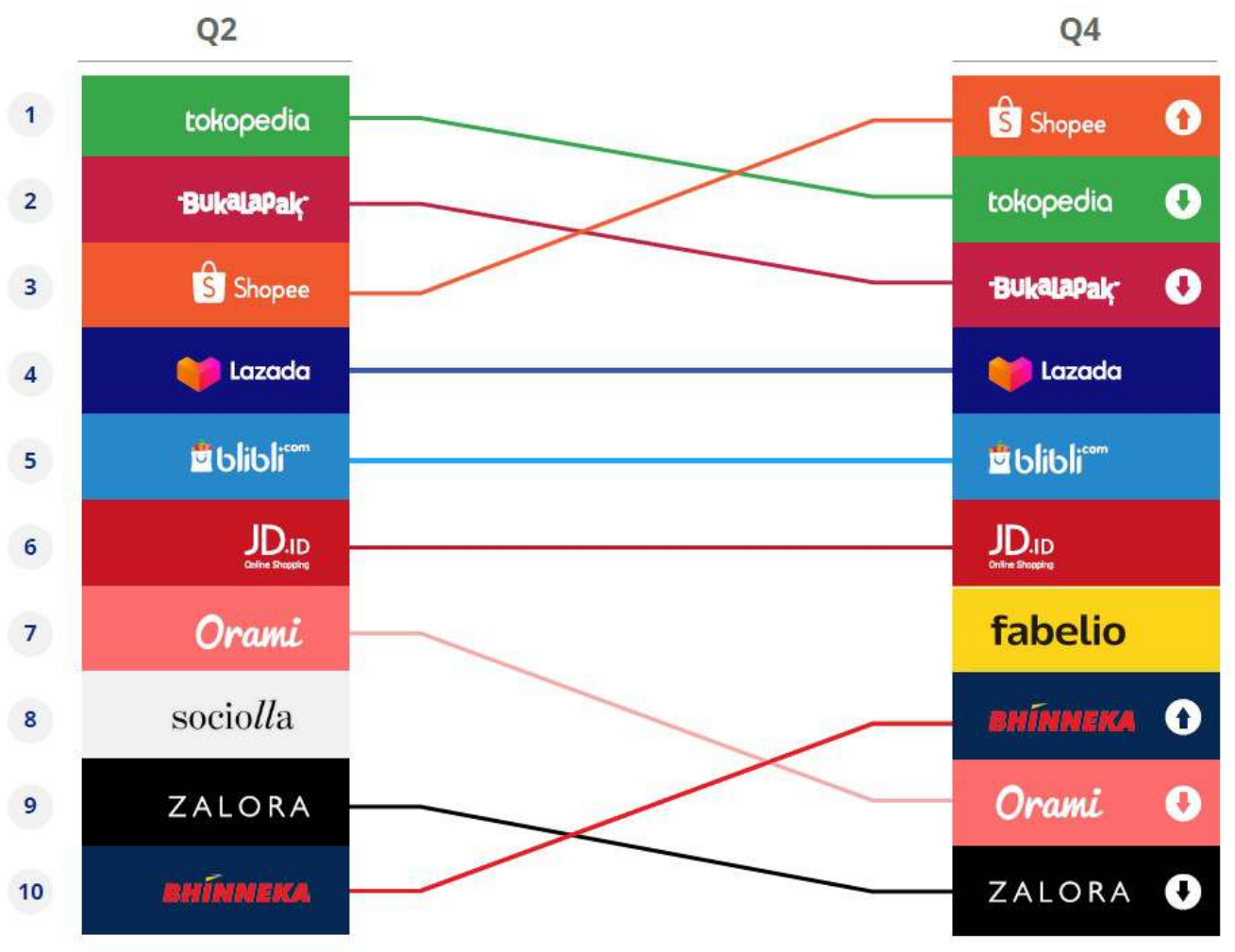

Figure 1. Comparison of the Most Visited E-commerce Sites (https://iprice.co.id/insights/mapofecommerce/)

\section{RESEARCH METHODOLOGY}

The method of writing this research with the study of literature by connecting between literature as a basis for argument. Literature search and sources of information related to Ecommerce marketing strategies are carried out to further analyze the information that has been obtained. In developing a framework of thinking it is also supported by data derived from survey institutions published in the mass media as well as data from institutions or interested parties related to discussions in ecommerce that encourage regional economic growth in Indonesia. The purpose of searching and processing information and literature is to obtain sustainable information so that relationships and conclusions are expected to be useful. The methodology used in making this paper is:

1. Finding and gathering information from various sources and literature from books, the internet, preexisting papers, and also other material related topics discussed.

2. Identifying information and determining relevance to the topic.

3. Record and gather information related to the topic.

4. Arrange, identify, and process important information that has been obtained in a structured and interrelated way.

5. Draw conclusions and provide suggestions based on the results obtained in the paper.

\section{RESULT AND DISCUSSION}

The industrial revolution 4.0 is a period of technological development that has implications used by organizations as changes and developments in services and the creation of existing products which are then developed or new types of products [6]. The characteristics of ecommerce are divided into four types based on Kotler (2012) [7]: 


\section{Business to Business}

a. Relationships between business people have been created and have undergone previous business transactions.

b. Mutual repetition of information that has occurred and has become a common reference.

c. The general process used is conformity and equality between actors in which the intelligence process.

\section{Business to Consumer}

a. The process is open to all information actors and also disseminated to the public.

b. Services that are used for the public and have a beneficial impact on society.

\section{Consumer to Consumer}

How do you use a business model that is on the website that helps promote merchandise while also providing online payment transaction facilities. The main concept for a website container in the marketplace:
a. All online transactions are facilitated by each marketplace's website.
b. Can be used for all sellers.

\section{Consumer to Business}

This model is a consumer model into a business where consumers act to create value from companies that are consumers and done digitally, namely:

a. Technology where as an intermediary for information in buying and selling transactions in the digital world with the internet network becomes a bridge or connector of its users.

b. Marketing is a channel between the seller and the buyer where the seller can provide information and market products and services without any restrictions that intend to connect directly between the seller and the buyer

c. Electronic economy, which is the beginning of the principle of economy, can be consumed by people without any restrictions and can be on all economic actors.

d. Tools or media that connect suppliers of goods and prospective buyers in an electronic relationship through the efficient exchange of information on time, space and energy.

e. The main source of the most important is information where this information is the core of the concept of virtual value chains which is an additional value process applied to information.

f. The creation of new markets in which trading markets are created that are virtually connected between sellers and buyers that are digitally bridged. the creation of the market is open, free of charge, and minimizes the energy used.

g. The creation of new services in the process of buying and selling in the form of supporting services to facilitate the process that creates safe and comfortable transactions. one example of this service is the service in financial transactions.

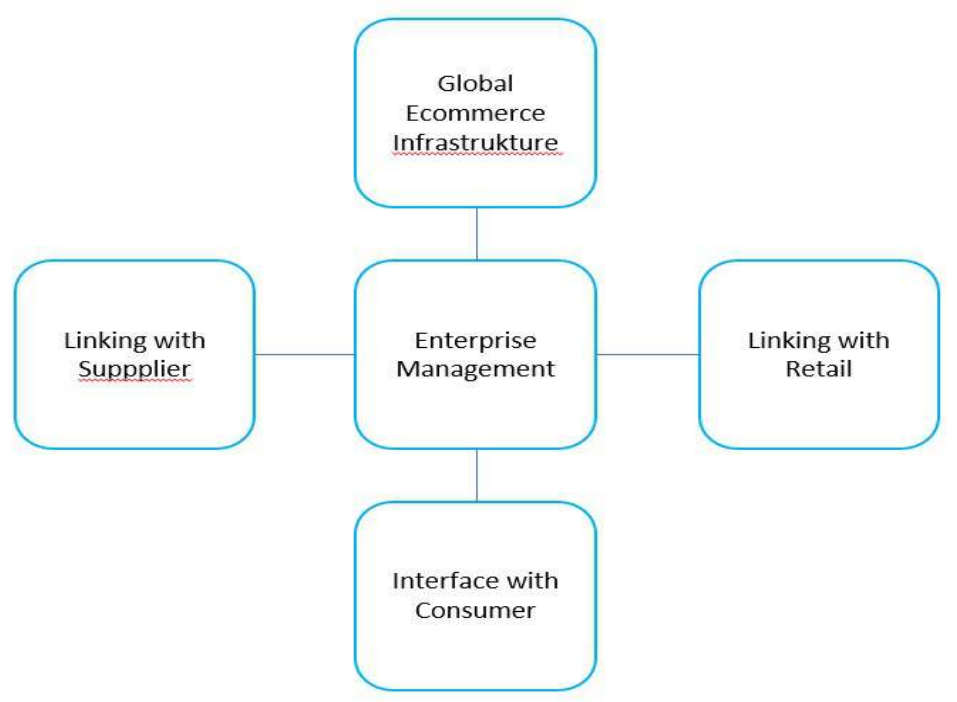

Figure 2. e-Commerce Scope 
Nine steps to develop internet marketing by ecommerce practitioners in the industrial era 4.0 [8]

1. Frame market opportunities

2. Formulate a marketing strategy

3. Designing and modifying consumer opportunities

4. Create a effectice communication with customer

5. Marketing program Plan

6. Increase customer communication through information technology usage

7. Competent character developmen and delegation

8. Creating a systematic market and customers

9. Evaluating marketing programs

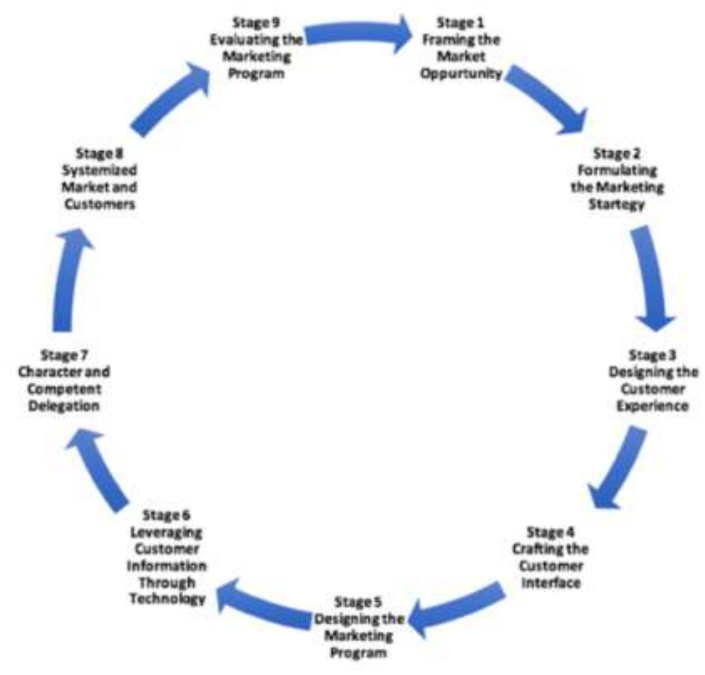

Figure 3. Chart of the Nine Steps to Ecommerce Development (R. Murdiana, Z. Hajaouib, 2020)

Framing market opportunities

Framing market opportunities is done by analyzing opportunities and benefits for each opportunity:

1. Opportunities in existing systems: scope used to identify areas to be targeted by companies that are new players and opportunities that are expected to be obtained to enable companies to take a role in the market.

2. Identification of consumer desires that cannot be fulfilled and served by other parties: innovating gives birth to new values based on activities and work processes well and see the items needed by consumers by identifying business processes in existing companies for and answering the question whether the system currently can meet consumer desires or not meet consumer expectations or not. The main activity in this area is to identify needs that have not been met.

3. Determine the target segment of consumers: segmentation can be interpreted the process of grouping or sorting consumers based on similarity. The consumer grouping approach can be divided into geographical groups, namely countries, states, provinces, districts. Based on demographics such as consumer age, generation, gender, based on type of work, ethnicity, income, race, family status, electricity usage, and type of browser. Firmographically based on differentiating markets based on companies and businesses and their industries. Behavior - online or conventional shopping behavior, internet usage, etc. Opportunities such as the use of time, location, events, special activities and others.

4. Requirements for bidding: the process by which important business actors, to consumers in the form of technologies and innovations that are expected to meet consumer desires. The resources that are already owned include resources faced by customers, internal and upstream 
5. Value of competitiveness, technology, and financial opportunities: everything that businesses can use to assess and create opportunities including the intensity of competition, customer dynamics, technological vulnerabilities, and microeconomics

6. Conduct an assessment of accept and no accept: Determination of accept and no accept, there are three measurement parameters, namely positive factors, neutral factors and negative factors.

Formulate a marketing strategy

Based on the decision in the previous stage, the steps taken then are to determine the ecommerce marketing strategy, namely:

1. Identify consumer segmentation in the market scope and determine the specified targets

2. Determine the position by using a matrix targeting approach in the evaluation and similarity of consumers.

Design customer opportunities

Three stages to building a customer experience:

1. Based on function

a. Usability and ease of use

b. Savings on time usage

c. Reliability

d. Security and privacy

e. Ease of obtaining information

2. Based on intimacy

3. Based on other things namely differences in communication, clarity, consistency.

\section{Create a customer interface}

The next step is to design a framework to identify the first appearance in business portrayal, namely to pay attention to the context in which the context provided is in accordance with the function and purpose and is interesting and can be a consumer's attention. images that can convey information clearly and create attraction for consumers. Creating relationships based on consumer desires and growing consumer ownership of the business. This modification can be done by companies or customers in updating content. Creating communication for the delivery of information that is between sellers to buyers, buyers to sellers, buyers to buyers. It needs high attention to show consumers in delivering good information on the transaction settlement process products in the transaction.

\section{Designing a marketing program}

Marketing program planning aims to combine marketing strategies with sales targets that have been determined in the previous stage. Relations between customers in the form of awareness of customers who begin to communicate and act in search of information, commitments involving responsibility for the product or company and buyers looking for information at a later date of settlement or dissolution where one of the parties terminates the relationship.

\section{Utilizing customer information through technology}

Technology can be used to obtain, analyze, and utilize information with the aim that the seller will be able to understand consumer demand. At this stage it can be done by conducting marketing research, database usage, customer relationship management which is a tool to determine profits and retain buyers by having the power and information of the buyer.

\section{Competent character and delegation}

Techniques in delegating include assigning and fully trusting, delegating tasks to the right people, delivering instructions clearly, delegating work based on interests and abilities, and setting deadlines and evaluations.

\section{Creating a systematic market and customers}

Good service is to provide services that exceed the expectations of buyers. The best service delivery aims to anticipate competition, utilize resources, create opportunities, place ideas, manage products find and compare new market opportunities for the right budget, create attraction. Factors associated with a systematic market are segment size, segment growth situation analysis, resource costs incurred, conformity of objectives, and implementation of target markets. 


\section{Evaluating marketing programs}

Evaluation of marketing programs can be done with a financial matrix that includes buyers by looking at marketing performance based on financially generated assets and based on implementation based on the effectiveness and efficiency of assets in satisfying buyers' desires.

Based on the literature outlined, we get a matrix of nine marketing strategies:

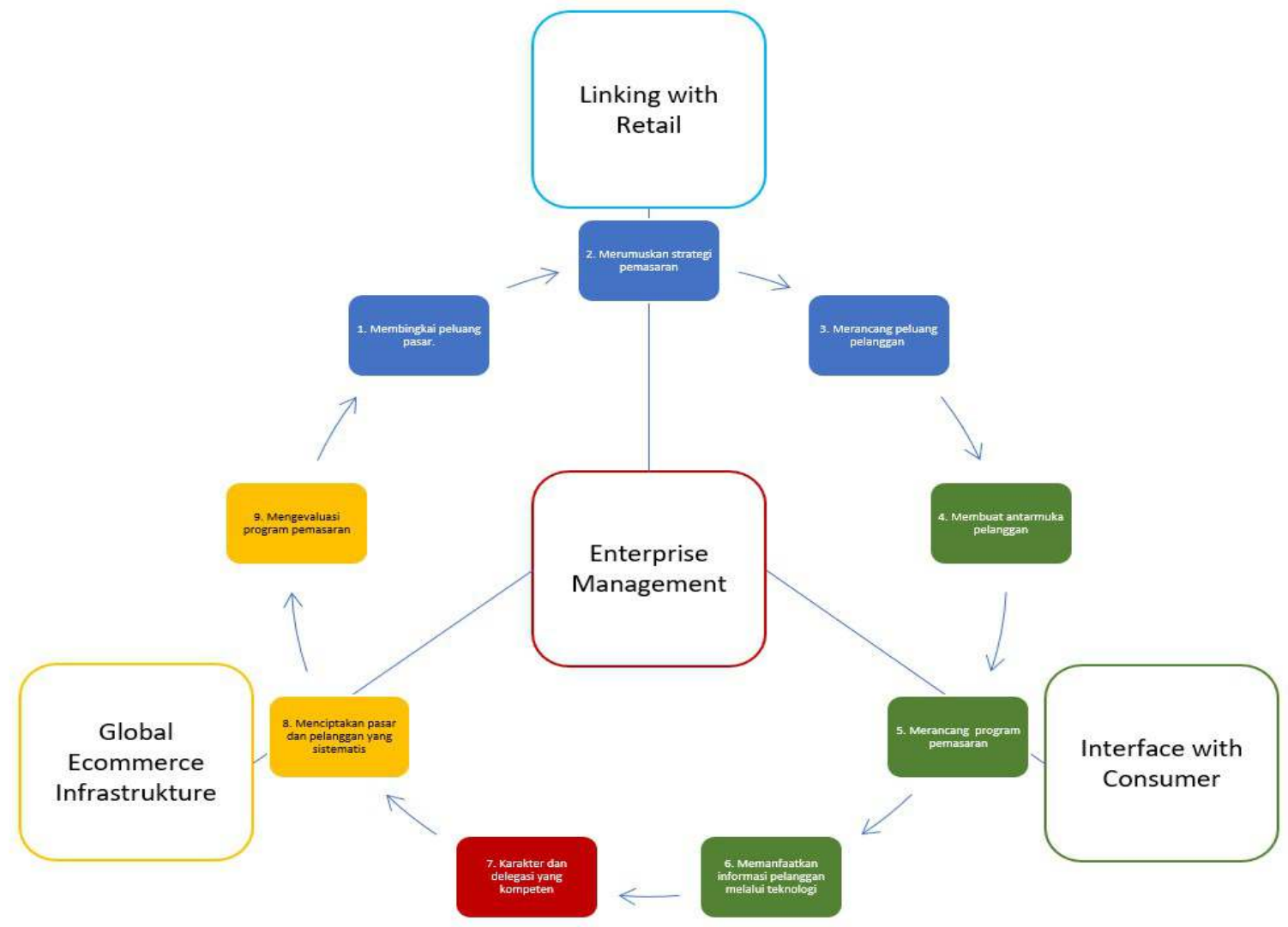

Figure 4. Nine Marketing Strategy in Industry 4.0 in the scope of e-commerce; Source: Marketing Strategies Analysis

\section{CONCLUSION}

This study evaluates the tools used in the scope of ecommerce by using the nine steps of ecommerce marketing in that marketing step covers three of the four scopes of ecommerce. The existence of the industrial revolution 4.0 has an impact on business development, markets, and consumers. Businesses have the opportunity to expand market share and with the expansion of market share will create business development that is accompanied by innovation. marketing strategies used in nine steps which include Global ecommerce, retail, consumer, and management through market frames, market opportunities, formulate strategies in marketing, customer design, consumer interfaces, programs in the marketing process, and information through digital technology, delegation competence, the creation of a systematic consumer market and program evaluation. Ecommerce activities require technology and innovation where extensive and up-to-date knowledge and information are needed by observing market developments and changes. By using resources owned by ecommerce businesses and being able to utilize technological developments for business continuity and enhancing and maintaining consumer confidence. 


\section{ACKNOWLEDGEMENT}

The authors would like to thank BINUS University, Indonesia and the Community Service Internal Grant Program in 2020 which has funded IMPLEMENTATION OF E-LEARNING IN SCHOOLS IN THE PRAMUKA ISLAND OF SERIBU ISLANDS - DKI JAKARTA

\section{REFERENCES}

[1] UGM, FORKOMSI FEB;, "Revolusi Industri 4.0," in Revolusi Industri 4.0, Yogyakarta, CV Jejak (Jejak Publisher), 2019, p. 12.

[2] T. L. Friedman, "Sejarah ringkas abad ke-21," in The World Is Flat, Jakarta, Dian Rakyat, 2006.

[3] J. K. Shim, A. A. Qureshi and R. M. Siegel, The International Handbook of Electronic Commerce, New York: Routledge, 2013.

[4] M. Suryanto, "Multimedia alat untuk meningkatkan keunggulan bersaing," in Multimedia alat untuk meningkatkan keunggulan bersaing, Yogyakarta, Andi, 2003.

[5] P. W. Miniard, S. Bhatla, K. R. Lord and P. R. Dickson, "Journal of consumer research," Picturebased persuasion processes and the moderating role of involvement, pp. 18(1), 92-107, 1991.

[6] R. Yazdanifard, M. Venpin, W. F. Yusoff and M. R. Islam, "Internet marketing," The new era of innovation in e-commerce. In International Conference on Software and Computer Applications, vol. 9, pp. 192-197., 2011.

[7] P. Kothler and K. Keller, Marketing Management 14th Edition, Upper Saddle River: Pearson Prentice Hall, 2012.

[8] R. Murdianaa and Z. Hajaouib, "Business Ecosystem \& Strategy," E-commerce marketing strategies in industry 4.0, vol. 2, p. 7, 2020. 